\title{
Hematological Parameters in Nile Tilápia, Oreochromis niloticus Exposed to Sub-letal Concentrations of Mercury
}

\author{
Nilton Massuo Ishikawa ${ }^{1 *}$, Maria José Tavares Ranzani-Paiva ${ }^{2}$, Julio Vicente \\ Lombardi $^{2}$ and Cláudia Maris Ferreira ${ }^{2}$ \\ ${ }^{1}$ Centro de Aqüicultura da UNESP; niltonmi@ caunesp.unesp.br; ${ }^{2}$ Centro de Pesquisa e Desenvolvimento de \\ Peixes Ornamentais; Instituto de Pesca SAA-APTA; Av. Francisco Matarazzo, 455; 05001-900; São Paulo - \\ SP-Brasil
}

\begin{abstract}
Mercury toxicity in tilapia, Oreochromis niloticus, (Linnaeus, 1758) was investigated by the hematological parameters after long-term (14 days) exposure to various $\mathrm{Hg}$ concentrations $(0.02,0.002,0.0002 \mathrm{mg} / \mathrm{L} \mathrm{Hg})$. Test groups were set up with three replicates for each concentration, plus the control group. Blood samples were collected from six individuals for each concentration at 0, 3, 7, 10 and 14 days of exposure. The hematological parameters analyzed were: total red blood cell count (RBC), hemoglobin concentration (Hb), hematocrit (Ht), mean corpuscular volume (MCV), mean corpuscular hemoglobin $(\mathrm{MCH})$, mean corpuscular hemoglobin concentration $(\mathrm{MCHC})$, total white blood cell count (WBC) and differential leukocyte counts and total thrombocyte count (Tr). There were no significant differences among the mean hematological values at the different $\mathrm{Hg}$ concentrations indicating that Hg at the concentrations studied was not toxic to tilapia.
\end{abstract}

Key words: Mercury, heavy metal pollution, fish, Oreochromis niloticus, hematology

\section{INTRODUCTION}

The discharge of effluents containing mercury $(\mathrm{Hg})$ into the environment has caused grave contamination problems in communities of various ecosystems and in human populations. Cases such as Minamata and Niigata in Japan, during the 1950s and 1960s, and in Iraq in the 1970s, reflect a high risk from this type of pollution. This stirred the attention of health authorities in relation to the contamination of rivers by industrial waste containing mercury, because besides being the most toxic among heavy metals, it is also accumulated in animals for long periods of time. Aquatic organisms produced in breeding systems are constantly exposed to pollutants, since the water utilized in the production process originates from rivers, lakes or sources that could be contaminated with Hg. Tavares (1995) showed that for aquatic organisms to develop and survive well, the conditions of the environment in which they live is of fundamental importance. The introduction of any substance in the water produces changes in its quality, which are not always favorable to the development and survival of aquatic organisms. Aquacultural organisms may bioaccumulate trace metals in their tissues and consequently threaten themselves directly. Standard toxicity tests laboratory performed are used extensively to predict the effects of chemicals in aquatic ecosystems (Tsai et al., 2005). According to Oliveira-Ribeiro et al. (1996) and Machado and Fanta

\footnotetext{
* Author for correspondence
} 
(2003), toxicity studies utilizing fish under controlled conditions provide, through the evaluation of mortality, behavioral, reproductive success, hematological changes and damage to tissues, important information corresponding to the effects of pollutants on the biota of a natural aquatic ecosystem.

The study of different biochemical and cellular constituents in blood is of fundamental importance in the physiological and physiopathological evaluation of animals, because morphological and quantitative variations in blood parameters can be induced by pollutants and other environmental factors (Juneja and Mahajan, 1983; Ranzani-Paiva et al., 1997). According to Nussey et al. (1995), the study of the hematological picture is frequently utilized for the detection of physiopathological changes in different stress conditions such as exposure to heavy metals. Changes in the hematological profile of the fish exposed to mercury have been observed in Hoplias malabaricus (Oliveira-Ribeiro et al., 2006), Tilapia mossambica (Menezes and Quasim, 1984), Oreochromis aureus (Allen, 1994), Acipenser baeri (Mikryakov and Lapirova, 1996), Ctenopharyngodon idella (Shakoori et al., 1994), Pleuronectes platessa (Fletcher and White, 1986), Channa punctatus (Juneja \& Mahajan, 1983; Sastry and Sharma, 1980), Aphanius dispar (Hilmy et al., 1980).

Tilapia (Oreochromis sp.) is one of the most important freshwater finfish in aquaculture world. Among the numerous regions now inhabited by tilapia, many are under threat from metal pollutants including mercury. There are many works using this species in bioassay tests in order to learn the effects of chemicals in aquatic ecosystems. Effects of some heavy metals in tilapia have been reported (Shaw and Handy, 2006; Tsai et al., 1995; Nussey et al., 1995; Allen, 1994; Cuvin-Aralar, 1994; Dangé, 1986; Menezes and Quasim, 1984). This fish species is commonly used in experimental work for its rusticity and good adaptation to the captivity conditions (Ranzani-Paiva et al., 2004, Baccarin and Camargo, 2005, Gordon et al., 2005; Molina et al., 2005).

The aim of this study was to evaluate the hematological effects of mercury in tilapia, Oreochromis niloticus, exposed to different sublethal concentrations.

\section{MATERIALS AND METHODS}

The experiments were performed in the laboratory of Aquatic Toxicology of the Fisheries Institute $\mathrm{SP}$, in an acclimatized environment (10L:14D photoperiod and water temperature of $25.3 \pm 1.06$ C). The fish utilized were tilapia, Oreochromis niloticus (with mean weight of $27.13 \pm 4.67 \mathrm{~g}$ and mean length of $12.44 \pm 0.84 \mathrm{~cm}$ ), acquired from a commercial fish farm. The acclimation period was $96 \mathrm{~h}$ in a tank of 2,500 L of capacity and during this period the fish were fed with commercial ration and observed to examine for possible variations that could interfere with the experiment. After this period, the fish were transferred to 250 $\mathrm{L}$ tanks and acclimated again for $48 \mathrm{~h}$, maintaining the same conditions of bioassay (location $\mathrm{x}$ density). At the end of this second acclimation, the fish were transferred to aquaria capable of holding $40 \mathrm{~L}$ of water, equipped with an artificial aeration system and coated internally with transparent plastic bags.

The chemical product employed was mercuric chloride $\left(99 \%, \mathrm{HgCl}_{2}\right)$ in the salt form, obtained from Synth Laboratory ${ }^{\mathrm{TM}}$. A stock solution of 10 $\mathrm{mg} / \mathrm{L}$ mercury was made by dissolving the salt in double-distilled water. This solution was diluted directly into aquaria in sufficient amounts to provide the following mercury concentrations in water: $0.02,0.002$ and $0.0002 \mathrm{mg} / \mathrm{L}$, which were estimated from the $\mathrm{LC}_{50-96 \mathrm{~h}} / 10, \mathrm{LC}_{50}$ ${ }_{96 \mathrm{~h}} / 100$ and $\mathrm{LC}_{50-96 \mathrm{~h}} / 1000$ (Ishikawa, 2003). The lowest concentration is the maximum concentration recommended by Conama (2005) for water to be used in the cultivation of aquatic organisms. An aquarium was maintained without the addition of $\mathrm{Hg}$ for the control group. This bioassay with the three different $\mathrm{Hg}$ concentrations and the control group was performed in triplicate. The exposure time to mercury was 14 days at a density of 16 fish per aquarium.

The fish were fed with extruded ration once each three days corresponding to approximately $1.5 \%$ of the bodyweight, followed by siphoning of the excrement. Subsequently, $1 / 3$ of the water was replaced by a solution previously prepared of the same $\mathrm{Hg}$ concentration. Every $24 \mathrm{~h}$, the temperature $\left({ }^{\circ} \mathrm{C}\right)$ of the water was recorded using a mercury thermometer; $\mathrm{pH}$ values were obtained with a $\mathrm{pH}$ meter and the electrical conductivity was measured $(\mu \mathrm{S} / \mathrm{cm})$. At the end of the experiment, the water was 
tested for total hardness $\left(\mathrm{mgCaCO}_{3} / \mathrm{L}\right)$, total alkalinity $\left(\mathrm{mgCaCO}_{3} / \mathrm{L}\right)$ and total ammonia $(\mathrm{mg} / \mathrm{L})$.

For hematological analyses, at the beginning of the experiment, blood was collected from six individuals before the distribution of the fish into the aquaria for time zero samples. Blood was collected from six individuals per concentration test at intervals of 3, 7, 10 and 14 days of exposure. Fish were anesthetized with benzocaine and the blood samples were obtained with a heparinized syringe from the caudal vein. The blood samples were used for determinations of the red blood cell (RBC) after dilution with Natt and Herrick (1952) solution and counted in a Neubauer chamber; hematocrit $(\mathrm{Ht})$ by the microhematocrit technique; hemoglobin level $(\mathrm{Hb})$ by the cyanomethemoglobin method; mean corpuscular volume (MCV), mean corpuscular hemoglobin $(\mathrm{MCH})$ and mean corpuscular hemoglobin concentration (MCHC); total thrombocyte and leukocytes counts (Hrubec and Smith, 2000), and differential leukocyte count in blood smears stained with May Grünwald-Giemsa, according to Rosenfeld (1947).

The water utilized in these experiments, with the exception of controls, was stored and treated before being discharged into the urban sewage system. This was done by adding sodium hydroxide until the solution reached a pH between 9 and 10 . Subsequently, a solution of sodium sulphate was added, which resulted in the crystallization of $\mathrm{Hg}$ and the consequent sedimentation of the chemical product. The water was discharged and the sediment was recovered and sent to the Center for Nuclear Energy in Agriculture - CENA, in Piracicaba, SP - Brazil, for final recycling. The data obtained from the hematological tests were submitted to analysis of variance to determine significant differences between the treatments and the control group for all of the exposure times.

\section{RESULTS AND DISCUSSION}

The physical and chemical parameters of the water utilized in the chronic toxicity test in tilapia (Table 1) did not show any changes that would interfere with the results among the treatments. Except for the high level of total ammonia, as determined according to Noga (1995), the quantity of unionized ammonia (UIA) were calculated as a function of $\mathrm{pH}$, temperature and total ammonia concentration. The UIA showed a mean of
$0.08 \mathrm{mg} / \mathrm{L}$. Hargreaves and Kucuk (2001) noted that concentrations of UIA below $0.28 \mathrm{mg} / \mathrm{L}$ had no significant effects on the growth rate, feed conversion and survival on the tilapia $O$. aureus. $\mathrm{Xu}$ et al. (2005) reported no behavior alteration in $O$. niloticus exposed to $0.13 \mathrm{mg} / \mathrm{L}$ of unionized ammonia. However, decreases in circulating erythrocytes in $O$. niloticus exposed to ammonia were reported by Ahamed et al. (1992). Hence, the observed decrease of $\mathrm{RBC}$ and $\mathrm{Ht}$ in the present study could be affected by the high level of ammonia.

In the present study the fish were deprived of food for two days before the blood collection and after feeding a commercial diet at $1.5 \%$ bodyweight.

The results obtained for the erythrocyte parameters of $O$. niloticus exposed to different concentrations of $\mathrm{Hg}$ did not differ significantly in relation to the concentrations tested over 14 days (Figure 1). However, when comparing separate exposure times, some treatments showed significant differences in relation to control. The reduction in mean of $\mathrm{Ht}$ values is due to a decrease in circulating $\mathrm{RBC}$ number, as reflected in the $\mathrm{MCV}$ values, occurring primarily at the highest concentration examined $(0.02 \mathrm{mg} / \mathrm{L})$. The mean values for total $\mathrm{Hb}$ varied between 4.0 and $6.2 \mathrm{~g} / \mathrm{dL}$, with a greater difference at a concentration of $0.0002 \mathrm{mg} / \mathrm{L} \mathrm{Hg}$, compared to control. In determining $\mathrm{Hb}$ content (MHC) and concentration (MCHC) in erythrocytes, a slight rise in mean values was observed during the course of the experiment, suggesting a small increase in erythrocytes volume and of the hemoglobin content inside.

The variations of the mean values for the red blood cell parameters are shown in Fig. 1, which demonstrated a decrease in RBC count and $\mathrm{Ht}$ for all groups exposed to different concentrations, including the control group. Shakoori et al. (1994), in studying grass carp, Ctenopharyngodon idella exposed to $\mathrm{HgCl}_{2} \quad(0.005 \mathrm{mg} / \mathrm{L})$, observed a decrease in RBC count, $\mathrm{Ht}$ and $\mathrm{Hb}$ level during the first two weeks of the experiment and a later increase in MCV after four weeks of exposure. Similar results were described for carp, Cyprinus carpio exposed to $\mathrm{HgCl}_{2}(0.30 \mathrm{mg} / \mathrm{L})$ for $90 \mathrm{~h}$ (Beena and Viswaranjan, 1987) and Aphanius díspar exposed to the same product $(1.0 \mathrm{mg} / \mathrm{L})$ for $96 \mathrm{~h}$ and 30 days (Hilmy et al., 1980). Pleuronectes platessa exposed to toxicity tests with $\mathrm{HgCl}_{2} \quad(0.3 \mathrm{mg} / \mathrm{L})$ showed same hematological changes, following splenomegaly. 
This organ is important to the phagocytic organ in the plaice, with avidity for erythrocytes (Fletcher and White, 1986). O'Connor and Fromm (1975) reported a decrease in RBCs number and $\mathrm{Ht}$, due to hemolysis as a consequence of $\mathrm{Hg}$ toxicity. On the other hand, some authors (Benfey and Biron, 2000; Affonso et al., 2002) suggested that inexperiment of toxicity a lowered $\mathrm{Ht}$ level could be related to the conditions of confinement or stress induced by the lack of food.

Different and divergent results could occur due to various factors, such as differences in body size, species, concentration of the test substance and the time of exposure (Fletcher and White, 1986). In Channa punctatus (Juneja and Mahajan, 1983) and O. aureus (Allen, 1994) exposed to sub-lethal concentration $(0.034-0.136$ and $0.5 \mathrm{mg} / \mathrm{L}$, respectively) of $\mathrm{HgCl}_{2}$ in water, was reported increase of RBC count and Ht. O'Connor and Fromm (1975) observed at the beginning of their experiments a fall in $\mathrm{Ht}$ and at the end of 12 weeks the opposite. There was mention of the possibility that erythropoietic tissues could have been stimulated in response to the decline in RBCs caused by hemolysis as a consequence of exposure to $\mathrm{Hg}$. In addition, Oliveira-Ribeiro et al. (2000) described that fish exposed to inorganic $\mathrm{Hg}$ dissolved in the water causes hypoxia, as a result of cellular hyperplasia in the secondary lamellae of the gills, diminishing the surface area for gas exchange. In response to respiratory difficulty, the organism stimulates an increase in $\mathrm{RBCs}, \mathrm{Hb}$ and $\mathrm{MCHC}$ as mechanism to enhance oxygen transfer (Affonso et al., 2002).

The total number of thrombocytes showed a tendency towards an increase at the end of 14 days of exposure to the metal. However, there were no significant differences between mercury-exposed animals and control that would demonstrate an effect by the concentrations tested (Fig. 2).
In the present study, no statiscal significance was found in leukocyte counts for all treatments. However, in all groups, the decrease observed in the total leukocytes number including the control group, was result of lymphopenia and neutropenia occurring in the first three days of exposure. Subsequently, stabilization was observed up to the end of the experiment at 14 days (Fig. 3). Similar finding was reported for Channa punctatus exposed to $0.25 \mathrm{mg} / \mathrm{L}$ of $\mathrm{HgCl}_{2}$ (Misra and Behera, 1992). Gill and Pant (1985) attributed the leucopenia to the stress caused by the bioassay type, which had also been demonstrated in several other vertebrates. Oncorhynchus mykis, and Salvelinus fontinalis, submitted to the stress of confinement and manipulation showed a reduction in number of WBC and a slight increase in thrombocytes total number (Benfey and Biron, 2000). Then, the stress leads to a redistribution of lymphocytes, mainly to lymphoid organs (thymus and anterior kidney), diminishing in the blood circulation, or to the destruction of lymphocytes in response to high levels of cortisol.

The monocytes number showed a variation at the beginning and to increase at the end of the experiment. No significant difference was noted between the treatments and the control group. Basophils and eosinophils were found in only a few fish, disable any interpretation of the effects of $\mathrm{Hg}$ in these cells.

Based on the hemogram results obtained in the present study, it was seen that mercury had no significant hematological effects.

Dawson (1990), testing $\mathrm{HgCl}_{2}$ on Scophthalmus aquousus at concentrations $(0.005$ and $0.01 \mathrm{mg} / \mathrm{L})$ similar to those utilized in the present study, obtained the same results. It was, therefore, possible that these two species were resistant to the toxic effects of $\mathrm{Hg}$ at these concentrations and more vulnerable to experimental stress.

Table 1 - Physical and chemical parameters of water in the bioassay with O.niloticus exposed to $\mathrm{HgCl}_{2}$

\begin{tabular}{lcccccc}
\hline $\begin{array}{c}\text { Trial } \\
(\mathrm{mg} / \mathrm{L})\end{array}$ & $\mathrm{pH}$ & $\begin{array}{c}\text { Conductivity } \\
(\mu \mathrm{S} / \mathrm{cm})\end{array}$ & $\begin{array}{c}\text { Water } \\
\text { Temperature }\left({ }^{\circ} \mathrm{C}\right)\end{array}$ & $\begin{array}{c}\text { Hardness } \\
\left(\mathrm{mgCaCO}_{3} / \mathrm{L}\right)\end{array}$ & $\begin{array}{c}\text { Alkalinity } \\
\left(\mathrm{mg} \mathrm{CaCO}_{3} / \mathrm{L}\right)\end{array}$ & $\begin{array}{c}\text { Total Ammonia } \\
(\mathrm{mg} / \mathrm{L})\end{array}$ \\
\hline Control & $6.77 \pm 0.25 \mathrm{a}$ & $126.73 \pm 39.19 \mathrm{~b}$ & $25.43 \pm 1.10 \mathrm{a}$ & $29.96 \pm 2.92 \mathrm{a}$ & $62.35 \pm 7.44 \mathrm{a}$ & $14.90 \pm 0.71 \mathrm{a}$ \\
0.02 & $7.03 \pm 1.02 \mathrm{a}$ & $112.88 \pm 31.29 \mathrm{c}$ & $25.28 \pm 1.12 \mathrm{a}$ & $28.70 \pm 0.00 \mathrm{a}$ & $50.16 \pm 3.28 \mathrm{a}$ & $11.30 \pm 1.09 \mathrm{~b}$ \\
0.002 & $7.03 \pm 0.72 \mathrm{a}$ & $133.28 \pm 40.38 \mathrm{ab}$ & $25.34 \pm 1.01 \mathrm{a}$ & $26.79 \pm 1.91 \mathrm{a}$ & $63.06 \pm 4.96 \mathrm{a}$ & $15.21 \pm 1.82 \mathrm{a}$ \\
0.0002 & $7.22 \pm 0.39 \mathrm{a}$ & $140.56 \pm 47.73 \mathrm{a}$ & $25.48 \pm 1.02 \mathrm{a}$ & $28.07 \pm 1.10 \mathrm{a}$ & $56.61 \pm 6.91 \mathrm{a}$ & $15.81 \pm 0.55 \mathrm{a}$ \\
\hline $\mathrm{CV}(\%)$ & 3.97 & 3.91 & 0.43 & 6.43 & 10.14 & 8.08 \\
\hline
\end{tabular}

$\mathrm{CV}=$ Coefficient of variation

Means, in same column, followed by the same letter are not significantly different $(\mathrm{p}<0.05)$. 

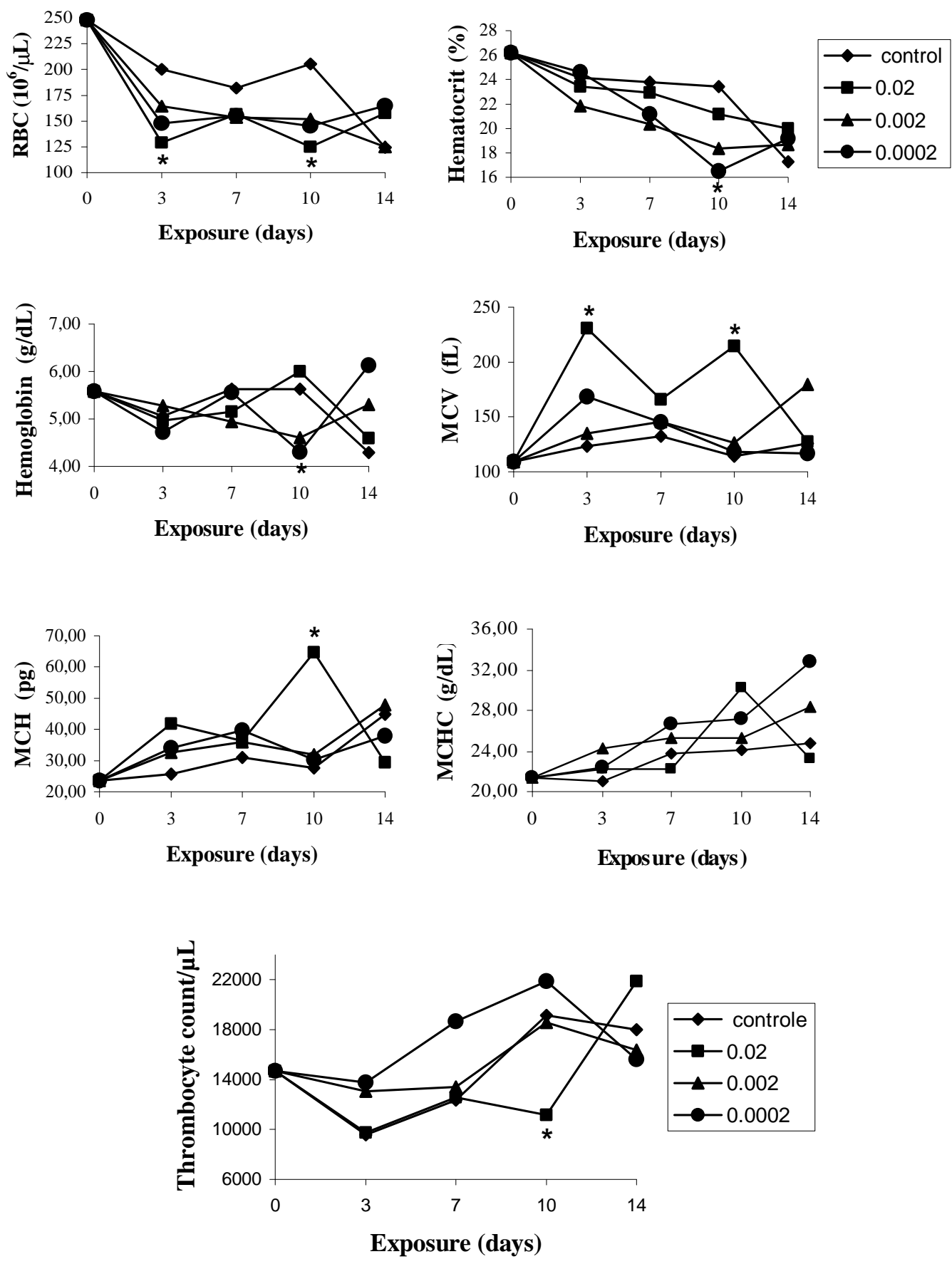

Figure 1 - Variation of mean values for erythrocyte parameters in O. niloticus, exposed to different concentrations of $\mathrm{HgCl}_{2}$, at different sampling times

(*) Significant different in relation to control group $(\mathrm{p}<0.05)$ 


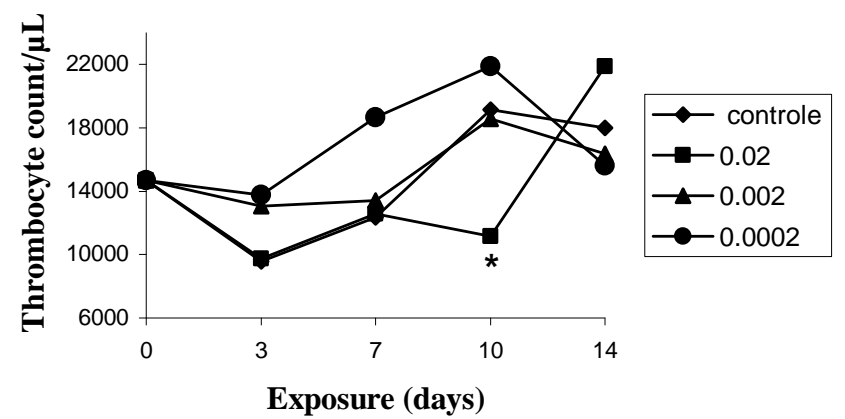

Figure 2 - Mean values of the total number of thrombocytes of $O$. niloticus, exposed to differents concentrations of $\mathrm{HgCl}_{2}$, at different sampling times.

(*) Significant different in relation to control group $(p<0.05)$
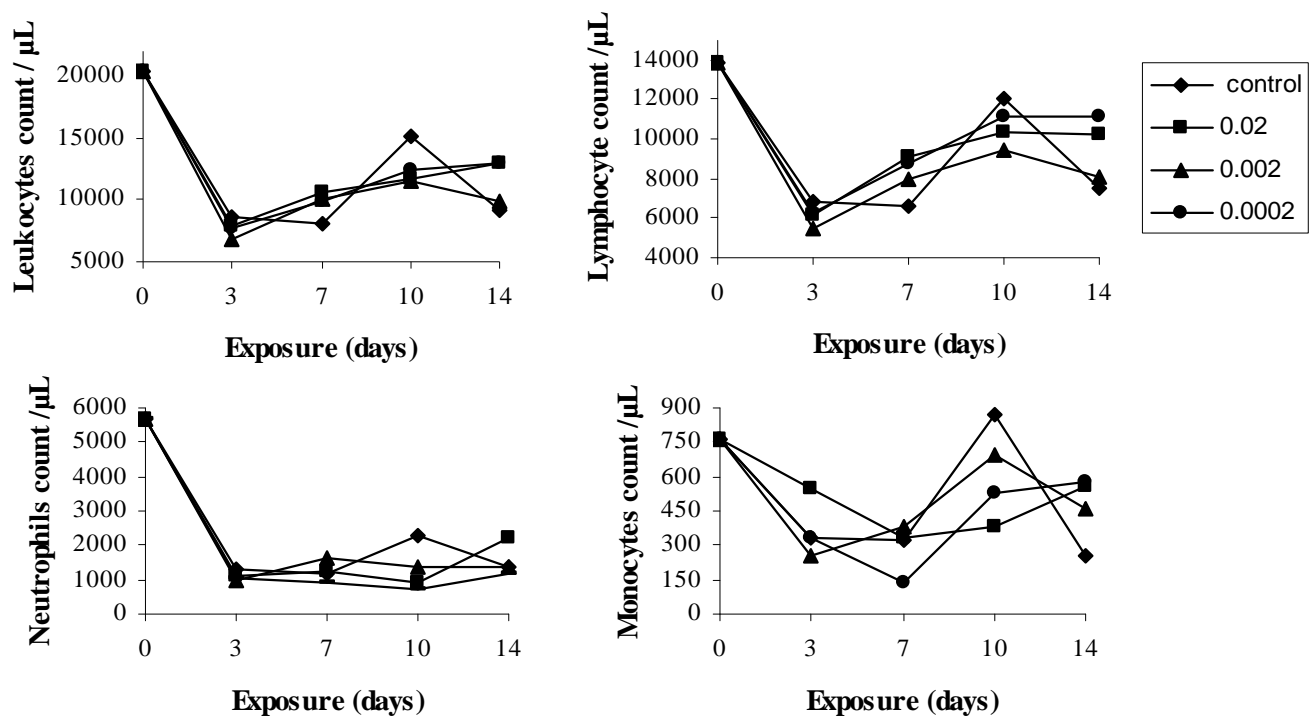

Figure 3 - Variation of mean values for the total number of leukocytes, lymphocytes, neutrophils and monocytes in peripheral blood of $O$. niloticus, exposed to differents concentrations of $\mathrm{HgCl}_{2}$, at different sampling times

\section{CONCLUSIONS}

The $\mathrm{Hg}\left(\mathrm{HgCl}_{2}\right)$ concentrations tested were insufficient to cause hematological changes in O. niloticus. Therefore, further studies of $\mathrm{Hg}$ toxicity would be need to be carried out at higher concentrations or using long exposure times.

\section{ACKNOWLEDGEMENTS}

This work was supported by the Fundação de Amparo a Pesquisa do Estado de São Paulo FAPESP (Process n: 2004/01236-9), Brazil.

\section{RESUMO}

A toxicidade do mercúrio foi avaliada em tilápia, Oreochromis niloticus (Linnaues, 1758) através da 
análise dos parâmetros hematológicos após exposição a diferentes concentrações sub-letais, durante um período de 14 dias. O bioensaio foi conduzido no laboratório de toxicologia do Instituto de Pesca, SP. Foram utilizados alevinos $(12.44 \pm 0.84 \mathrm{~cm}$, e $27.13 \pm 4.67 \mathrm{~g})$ e aquários com capacidade para 50 litros e preenchidos com água declorada e mais a quantidade de solução de mercúrio $\left(\mathrm{HgCl}_{2}\right)$ correspondendo as seguintes concentrações: 0,$02 ; 0,002 ; 0.0002 \mathrm{mg} . \mathrm{L}^{-1} \mathrm{Hg}$. Foram utilizadas 3 repetições de cada concentração e grupo controle. Amostras de sangue foram coletadas de seis animais de cada concentração nos tempos $0,3,7,10$ e 14 dias de exposição. Foram avaliados: a contagem de eritrócitos (RBC), concentração de hemoglobina $(\mathrm{Hb})$, hematócrito $(\mathrm{Ht})$, volume corpuscular médio (VCM), hemoglobina corpuscular média (HCM) e concentração de hemoglobina corpuscular média $(\mathrm{CHCM})$, trombócitos totais (Tr), contagem diferencial e total de leucócitos (Lc). Os resultados demonstram que as concentrações de $\mathrm{Hg}$ testadas, não alteraram significativamente os parâmetros hematológicos, permitindo concluir que a quantidade de $\mathrm{Hg}$ na água não foram suficientes para afetar o quadro hematológico de Oreochromis niloticus.

\section{REFERENCES}

Affonso, E.G.; Polez, V.L.P.; Corrêa, C.F.; Mazon, A.F.; Araújo, M.R.R.; Moraes, G. and Rantin, F.T. (2002), Blood parameters and metabolites in the teleost fish Colossoma macropomum exposed to sulfide or hypoxia. Comp.Biochem.Physiol. C, 133, $375-382$.

Ahmed, N.A.; El-Serafy, S.S.; El-Shaey, A.A.M. and Abdel-Haimide, N.H. (1992), Effect of ammonia on some haematological parameters of Oreochromis niloticus. Proc. Zool. Soc. AR Egypt, 23: (1), 155-160

Allen, P. (1994). Changes in the haematological profile of the cichlid Oreochromis aureus (Steindachner) during acute inorganic mercury intoxication. Comp. Biochem. Physiol. C, 108: (1), 117-121.

Baccarin, A.E. and Camargo A.F.M. (2005), Characterization and evaluation of the impact of feed management on the effluents of Nile Tilapia (Oreochromis niloticus) culture. Braz. Arch. Biol. Technol., 48: (1), 81 - 90.

Benna, S. and Viswaranjan S. (1987), Effect of cadmium and mercury on the hematological parameter of the fish Cyprinus carpio. Environ. Ecol., 5: (4), 726-732.
Benfey, T.J. and Biron, M. (2000), Acute stress response in triploid rainbow trout (Oncorhynchus mykiss) and brook trout (Salvelinus fontinalis). Aquaculture, 184, 167-176.

Conama. (2005), Resolução $n^{\circ} 357$, de 17 de março de 2005. Ministério do Meio Ambiente. Conselho Nacional do Meio Ambiente. Publicação D.O.U.: 18/03/2005. Disponível em:

http://www.mma.gov.br/port/conama/res/res05/res3570 5.pdf Acesso em: 18 de abril. 2006.

Cuvin-Aralar, M.L.A. (1994), Survival and heavy metal accumulation of two Oreochromis niloticus (L.) strains exposed to mixtures of zinc, cadmium and mercury. The Science of the Total Environment, 148: (1), 31-38.

Dangé, A.D. (1986), Changes in carbohydrate metabolism in tilapia, Oreochromis (Sarotherodon) mossambicus, during short-term exposure to different types of pollutants. Environ. Pollut. Series A, Ecol. Biol., 41: (2), 165-177.

Dawson, M.A. (1990), Blood chemistry of the windowpane flounder Scophthalmus aquosus in Long Island sound: geographical, seasonal, and experimental variations. Fish. Bull., 88: (3), 429-437.

Fletcher, T.C. and White, A. (1986), Nephrotoxic and haematological effects of mercuric chloride in the plaice (Pleuronectes platessa). Aquat. Toxicol., 8, 77-84.

Gill, T.S. and Pant, J.C. (1985), Mercury-induced blood anomalies in the freshwater teleost, Barbus conchonius. Water Air and Soil Pollution, 24: (2), 165-171.

Gordon, A.S.; Gordon, E.P. and Dyer, B.J. (2005). Susceptibility of two fishes (Oreochromis niloticus and Cyprinodon variegatus) to Pfiesteria shumwayae and associated toxin: Influence of salinity. Harmful Algae, in prees.

Hargreaves, J.A. and Kucuk, S. (2001), Effects of diel un-ionized ammonia fluctuation on juneline hybrid striped bass, channel catfish, and blue tilapia. Aquaculture, 195, 163-181.

Hilmy, A.M.; Shabana, M.B. and Said, M.M. (1980), Haematological responses to mercury toxicity in the marine teleost, Aphanius dispar (RÜPP). Comp. Bioch. Physiol., 67C, 147-158.

Hrubec, T.C. and Smith, S.A. (2000), Hematology of fish. Pages 1120-1125. In Schalm's Veterinary Hematology, ed. Feldman, B.F.; Zinkl J.G. and Jain, N.C. 5th ed. Lippincott Williams \& Wilkins, Canadá.

Ishikawa, N. M. (2003), Toxicidade aguda e crônica do mercúrio em tilápia "Tailandesa", Oreochromis niloticus. Determinação da $\mathrm{CL}_{50-96 \mathrm{~h}}$ e alterações hematológicas. Master's thesis. Centro de Aqüicultura da Universidade Estadual Paulista, Jaboticabal, São Paulo, Brazil.

Juneja, C.J. and Mahajan, C.L. (1983), Hematological and haemopoietic changes in fish Channa punctatus due to mercury pollution in water. Indian Journal of Animal Research, 17: (2), 63-71. 
Kikrayakov, V.R. and Lapirova, T.B. (1997), Influence of Salts of Some Heavy Metals on the Differential Blood Count in Juvenile Acipenser baeri. J. Ichthyol., 37: (6), 458-462.

Machado, M.R. and Fanata, E. (2003), Effects of the Organophosphorous Methyl Parathion on the Branchial Ephitelium of a Freshwater Fish Metynnis roosevelt. Braz. Arch. Biol. Technol., 46: (3), 361372.

Menezes, M.R. and Qasim, S.Z. (1984), Effects of mercury accumulation on the electrophoretic patterns of the serum, haemoglobin and eye lens proteins of Tilapia mossambica (Peters). Water Research, 18: (2), 153-161

Misra, S.K. and Behera, S.C. (1992), Evaluation of toxic effects of mercuric chloride on hematological parameters of a freshwater fish Channa punctatus (Bloch). Environ. Ecol., 10: (2), 394-396.

Molina, R; Moreno, I.; Pichardo, S.; Jos, A.; Moyano, R.; Monterde, J.G. and Cameán, A. (2005), Acid and alkaline phosphatase activities and pathological changes induced in Tilapia fish (Oreochromis sp.) exposed subchronically to microcystins from toxic cyanobacterial blooms under laboratory conditions. Toxicon, 46, 725-735.

Natt, M.P. and Herrick, C.A. (1952), A new blood diluent for counting the erythrocytes and leucocytes of the chicken. Poultry Science, 31: (1) 735 - 738

Noga, E.J. (1995), Fish Disease: Diagnosis and treatment. Mosby-Year Book. St. Louis, Missouri, USA.

Nussey, G.; Van Vuren, J.H.J. and du Preez, H.H. (1995), Effect of copper on the haematology and osmoregulation of the Mozambique tilápia, Oreochromis mossambicus (Cichlidade). Comp. Biochem. Physiol. 111C: (3), 369-380.

O'Connor, D.V. and Fromm, P.O. (1975), The effect of methyl mercury on gill metabolism and blood parameters of Rainbow trout. Bull. Environ. Contam. Toxicol., 13: (4), 406-411.

Oliveira-Ribeiro, C.A.; Guimarães, J.R.D. and Pfeiffer, W.C. (1996), Accumulation and distribution of inorganic mercury in a tropical fish (Trichomycterus zonatus). Ecotoxicology and Environmental Safety, 34, 190-195.

Oliveira-Ribeiro, C.A.; Pelletier, E.; Pfeiffer, W.C. and Rouleau, C. (2000), Comparative uptake, bioaccumulation, and gill damages of inorganic mercury in tropical and Nordic freshwater fish. Environmental Research, Section A., 83, 286-292.

Oliveira-Ribeiro, C.A.; Neto, F.F.; Mela, M.; Silva, P.H.; Randi, M.A.F.; Rabitto, I.S.; Alves Costa, J.R.M. and Pelletier, E. (2006), Hematological findings in neotropical fish Hoplias malabaricus exposed to subchronic and dietary doses of methylmercury, inorganic lead, and tributyltin chloride. Environmental Research, 101, 74-80.
Ranzani-Paiva, M.J.T.; Ishikawa, C.M.; Campos B.E.S. and Eiras, A.C. (1997), Haematological characteristics associated with parasitism in mullets, Mugil platanus Günther, from the estuarine region of Cananéia, São Paulo, Brasil. Revta Bras. Zool., 14: (2), 329-339.

Ranzani-Paiva, M.J.T.; Ishikawa, C.M.; Eiras, A.C. and Silveira, V.R. (2004), Effects of an Experimental Challenge with Mycobacterium marinum on the Blood Parameters of Nile Tilapia, Oreochromis niloticus (Linnaeus, 1757). Braz. Arch. Biol. Technol., 47: (6), 945-953.

Rosenfeld, G. (1947), Método rápido de coloração de esfregaços de sangue. Noções práticas sobre corantes pancrômicos e estudo de diversos fatores. Mem. Inst. Butantan, 20, 315-328.

Sastry, K.V. and Sharma, K. (1980), Mercury induced haematological and biochemical anomalies in Ophiocephalus (Channa) punctatus. Toxicology Letters, 5: (3-4), 245-249.

Shaw, B.J. and Handy, R.D. (2006), Dietary cooper exposure and recovery in Nile tilapia, Oreochromis niloticus. Aquatic Toxicology, 76, 111-121.

Shakoori, A.R.; Iqbal, M.J.; Mughal, A.L. and Ali, S.S. (1994), Biochemical changes induced by inorganic mercury on the blood, liver and muscles of freshwater Chinese grass carp, Ctenopharyngodon idella. Journal of Ecotoxicology and Environmental Monitory, 4: (2), 81-92.

Tavares, L.H.S. (1995), Limnologia Aplicada à Aqüicultura. Boletim Técnico 1. Jaboticabal, SP. Brazil.

Tsai, Ching-Lin; Jang, Te-Hsuan and Wang, Li-Hsueh. (1995), Effects of mercury on serotonin concentration in the brain of tilapia, Oreochromis mossambicus. Neuroscience Letters, 184, 208-211.

Tsai, Jeng-Wei; Liao, Chung-Min; Liao, V. HsiuChuan. (2006), A biologically based damage assessment model to enhance aquacultural water quality management. Aquaculture 251, 280-294

$\mathrm{Xu}$, Jian-yu; Miao, Xiang-wen; Liu, Ying and Cui, Shao-rong. (2005), Behavioral response of tilapia (Oreochromis niloticus) to acute ammonia stress monitored by computer vision. Journal of Zhejiang University SCI, 6B: (8), 812-81.

Received: August 15, 2005; Revised: June 01, 2006; Accepted: March 14, 2007. 
